\title{
KOMPETENSI DOSEN, PROFESIONALISME DOSEN, DAN KECERDASAN SPRITUAL DAMPAKNYA TERHADAP MOTIVASI BELAJAR MAHASISWA
}

\section{COMPETENCE OF LECTURER, LECTURER, AND PROFESSIONALISM SPIRITUAL INTELLIGENCE IMPACT ON STUDENT LEARNING MOTIVATION}

\author{
Mochamad Hatip, Khoiriyah, dan Abadi Sanosra, Nurul Qomariah \\ Universitas Muhammadiyah Jember \\ Email: hatip_moch@unmuhjember.ac.id, khoiriyah@unmuhjember.ac.id \\ abadisanosra78@gmail.com, nurulqomariah@unmuhjember.ac.id
}

\begin{abstract}
ABSTRAK
Penelitian ini bertujuan untuk mengetahui pengaruh kompetensi dosen, profesionalisme dosen, dan kecerdasan spiritual dosen terhadap motivasi belajar pada Universitas Muhamamdiyah di Jawa Timur. Populasi dalam penelitian ini adalah seluruh mahasiswa yang terdaftar pada Universitas Muhammadiyah di Jawa Timur dengan jumlah mahasiswa 56.400 orang. Penentuan sampel penelitian menggunakan metode stratified random sampling untuk setiap universitas yang diperoleh dengan menggunakan rumus Slovin dengan tingkat keyakinan 90\% diperoleh sampel sebanyak 135 mahasiswa. Penelitian ini dianalisis dengan menggunakan Analisis Path dengan metode SEM. Hasil penelitian menunjukkan bahwa kompetensi dosen berpengaruh signifikan terhadap motivasi belajar mahasiswa Universitas Muhammadiyah di Jawa Timur. Profesionalisme dosen berpengaruh signifikan terhadap motivasi belajar mahasiswa Universitas Muhammadiyah di Jawa Timur. Kecerdasan spiritual dosen tidak berpengaruh signifikan terhadap motivasi belajar mahasiswa Universitas Muhammadiyah di Jawa Timur.
\end{abstract}

Kata Kunci : Kompetensi Dosen, Profesionalisme Dosen, Kecerdasan Spiritual dosen, Motivasi Belajar.

\begin{abstract}
This study aims to determine the effect of lecturer competence, lecturer professionalism, and the spiritual intelligence of lecturers on learning motivation at Muhammadiyah University in East Java. The population in this study were all students enrolled at Muhammadiyah University in East Java with a total of 56,400 students. Determination of the research sample using the stratified random sampling method for each university obtained by using the Slovin formula with a $90 \%$ confidence level obtained a sample of 135 students. This study was analyzed using Path Analysis with SEM method. The results showed that the lecturers' competence had a significant effect on the learning motivation of students of Muhammadiyah University in East Java. Professionalism of lecturers has a significant effect on the learning motivation of students of Muhammadiyah University in East Java. The lecturer's spiritual intelligence does not significantly influence the learning motivation of Muhammadiyah University students in East Java.
\end{abstract}

Keywords: Lecturer Competence, Lecturer Professionalism, Lecturer Spiritual Intelligence, Learning Motivation. 


\section{PENDAHULUAN}

Pendidikan merupakan salah satu cara dalam upaya mencerdaskan generasi muda. Di dalam sistem pendidikan nasional disebutkan bahwa pemerintah memberi kesempatan kepada lembaga pendidikan swasta untuk berperan dalam mencerdasakan generasi muda. Peran dosen sangatlah penting didalam meningkatkan prestasi mahasiswa di perguruan tinggi. Peningkatan prestasi mahasiswa ini sangatlah penting diperhatikan mengingat saat ini persaingan yang semakin meningkat. Dalam dekade terakhir ini, tantangan yang dihadapi kaum terdidik di lapangan pekerjaan kian berat. Tantangan yang paling utama adalah tingkat persaingan lapangan kerja yang semakin sempit, sementara dunia pendidikan terus mencetak anak didiknya di semua jurusan. Belum lagi dengan gempuran teknisi-teknisi handal dari luar yang akan masuk ketika MEA diberlakukan.

Berdasarkan data Organization for Economic Co-operation Development (OECD) 2012, Indonesia diprediksi menjadi negara dengan jumlah sarjana terbanyak kelima di dunia pada tahun 2020. Data tersebut merupakan proyeksi dari berbagai program peningkatan jumlah lulusan perguruan tinggi yang dilaksanakan setiap tahunnya. Namun, penyerapan lulusan sarjana di Indonesia tergolong lambat. Sampai saat ini sebanyak 442.000 lulusan sarjana di Indonesia masih menganggur dan masih mencari pekerjaan. Jumlah ini mewakili 5,5\% dari total tingkat pengganguran terbuka di Indonesia yang mencapai 7,17 juta orang (data Badan Pusat Statistik 2013). Berdasarkan fenomena yang ada maka peran perguruan tinggi baik negeri maupun swasta sangatlah penting dalam meningkatkan motivasi belajar sehingga prestasi mahasiswa dapat meningkat yang akhirnya lulusan perguruan tinggi dapat bersaing dalam memperoleh pekerjaan.

Motivasi belajar adalah suatu tenaga dari dalam yang menyebabkan kita berbuat yang mana tindakan itu diarahkan kepada tujuan tertentu yang hendak dicapai. Motivasi adalah suatu keadaan dalam individu yang menyebabkan seseorang, melakukan kegiatan tertentu untuk mencapai tujuan yang tertentu. Berbagai hal yang biasanya terkandung dalam berbagai definisi tentang motivasi antara lain adalah keinginan, harapan, kebutuhan, tujuan, sasaran, dorongan dan insentif. Dengan demikian dapat dikatakan bahwa motif adalah keadaan kejiwaan yang mendorong, mengaktifkan atau menggerakkan dan motif itulah yang mengarahkan dan menyalurkan perilaku, sikap dan tindak tanduk seseorang yang selalu dikaitkan dengan pencapaian tujuan, baik tujuan organisasi maupun tujuan pribadi masingmasing anggota organisasi yang bersangkutan. Karena itulah dapat dikatakan bahwa 
bagaimanapun motivasi didefinisikan, terdapat tiga komponen utamanya, yaitu kebutuhan, dorongan, dan tujuan. Kebutuhan, yang apabila ia merasa adanya kekurangan dalam dirinya. Dalam pengertian homoestatik, kebutuhan timbul atau diciptakan apabila dirasakan adanya ketidakseimbangan antara apa yang dimiliki dengan apa yang menurut persepsi yang bersangkutan seyogyanya dimilikinya, baik dalam arti fisiologis maupun psikologis. Misalnya apabila seseorang lapar, akan timbul kebutuhan untuk menghilangkan rasa lapar tersebut. Begitu seseorang makan, yang berarti situasi ketidakseimbangan telah hilang.

Motivasi belajar mahasiswa adalah keseluruhan daya penggerak di dalam diri mahasiswa yang menimbulkan kegiatan belajar/proses perkuliahan yang menjamin kelangsungan dan yang memberikan arah pada kegiatan belajar, sehingga tujuan yang dikehendaki oleh subjek belajar itu dapat tercapai. Motivasi memegang peranan yang sangat penting dalam kegiatan belajar di perguruan tinggi, dan motivasi dipengaruhi oleh tujuan yang akan dicapai dengan belajar. Makin tinggi tujuan belajar maka akan semakin besar pula motivasinya, dan semakin besar motivasi belajarnya akan semakin kuat pula kegiatan belajarnya. Ketiga komponen kegiatan atau perilaku belajar tersebut, saling berkaitan erat dan membentuk suatu kesatuan yang disebut sebagai proses motivasi belajar. Banyak factor yang dapat meingkatkan motivasi belajar mahasiswa.

Salah satu faktor yang dapat mempengaruhi peningkatan motivasi belajar mahasiswa adalah kompetensi dosen. Kompetensi dosen adalah kemampuan (baik pengetahuan, sikap dan keterampilan) yang harus dimiliki oleh seorang dosen untuk melaksanakan dan mempertanggungjawabkan tugas-tugasnya sesuai dengan petunjuk yang telah ditetapkan. Mengacu pada Undang-Undang RI No. 14 Tahun 2005 tentang guru dan dosen, untuk dapat menjadi dosen yang profesional seseorang harus memiliki empat kompetensi yakni kompetensi pedagogik, kompetensi kepribadian, kompetensi sosial dan kompetensi profesional. Kompetensi guru dan dosen terkait dengan kewenangan melaksanakan tugasnya, dalam hal ini dalam menggunakan bidang studi sebagai bahan pembelajaran yang berperan sebagai alat pendidikan, dan kompetensi pedagogis yang berkaitan dengan fungsi guru dan dosen dalam memperhatikan perilaku peserta didik belajar/ mahasiswa (Fitri, 2012). Martini dan Welas (2013) menyatakan bahwa kompetensi dosen dapat meningkatkan motivasi belajar mahasiswa. Mahesta (2015) menyatakan bahwa kompetensi dosen dapat meningkatkan motivasi belajar mahasiswa pada mahasiswa Universitas Widyatama. Tahrir (2013) dalam penelitiannya juga menyatakan bahwa kompetensi dosen berpengaruh secara linier 
terhadap motivasi belajar mahasiswa Fakultas Psikologi UIN Sunan Gunung Djati Bandung angkatan 2010-2011.

Faktor berikutnya yang dapat menentukan peningkatan motivasi belajar mahasiswa adalah profesionalisme dosen. Profesi adalah suatu pekerjaan yang menuntut keahlian tertentu pelakunya. Jadi dapat diisyaratkan profesi merupakan pekerjaan yang membutuhkan pelatihan dan penguasaan terhadap suatu pengetahuan khusus. Tetapi pada penerapannya perlu penguasaan teori sistematis yang mendasari praktek pelaksanaan, dan hubungan antara teori dan penerapan dalam praktek tersebut dalam cakupan pekerjaan itu sendiri. Profesi berasal dari kata profession, serta profesional berasal dari kata professional, yang mempunyai batasan bervariasi tergantung dari konteks yang ingin diungkapkan. Etika profesi itu berkaitan dengan baik dan buruknya tingkah laku individu dalam suatu pekerjaan, yang telah diatur dalam kode etik. Suatu profesi biasanya terikat dengan kode etik profesi , asosiasi profesi, serta proses sertifikasi dan lisensi yang khusus untuk bidang profesi tersebut. Kode etik profesi: organisasi profesi biasanya memiliki kode etik bagi para anggotanya dan prosedur pendisiplinan bagi mereka yang melanggar aturan. Hal ini digunakan untuk menghindari terjadinya penyimpangan kode etik sehingga menurunkan kehormatan profesi itu sendiri. Setiap orang dimungkinkan memiliki pekerjaan namun tidak semua pekerjaan itu sama jenisnya karena hal tersebut diukur dari tingkat kesulitan dan pendidikan yang ditempuh oleh orang itu untuk memperoleh pekerjaan itu sendiri. Adapun profesi adalah suatu pekerjaan yang menuntut keahlian tertentu pelakunya. Jadi dapat diisyaratkan profesi merupakan pekerjaan yang membutuhkan pelatihan dan penguasaan terhadap suatu pengetahuan khusus. Tetapi pada penerapannya perlu penguasaan teori sistematis yang mendasari praktek pelaksanaan, dan hubungan antara teori dan penerapan dalam praktek tersebut dalam cakupan pekerjaan itu sendiri. Penelitian tentang hubungan antara profesionalisme guru/dosen dengan motivasi belajar mahasiswa sudah banyak yang melakukan. Penelitian Manahen ( 2010) menyatakan bahwa profesionalisme guru dapat meningkatkan motivasi belajar siswa. Mahmud dkk. (2017) meyatakan bahawa profesionalisme guru berpengaruh berpengaruh sebesar 13,69\% terhadap motivasi belajar siswa.

Faktor berikutnya yang dapat mempengaruhi motivasi belajar adalah kecerdasan spiritual dosen. Kecerdasan spiritual merupakan suatu kemampuan yang terdiri dari tiga aspek, yaitu: aspek pertama yaitu aspek direction yaitu kemampuan untuk memusatkan kepada suatu masalah yang harus dipecahkan, aspek kedua yaitu aspek adaptation yaitu 
kemampuan untuk mengadakan adaptasi terhadap masalah yang dihadapinya atau fleksibel di dalam menghadapi masalah, dan yang ketiga yaitu aspek criticsm yaitu kemampuan untuk mengadakan kritik, baik terhadap masalah yang dihadapi maupun terhadap dirinya sendiri. Adapun Goleman (2006) mengemukakan bahwa intelegensi adalah kemampuan individu untuk memberikan respon yang tepat (baik) terhadap stimulus yang diterimanya. Dalam Emotional Spiritual Quotient (ESQ) mendefinisikan kecerdasan spiritual sebagai kemampuan untuk memberi makna ibadah terhadap setiap perilaku dan kegiatan melalui langkah-langkah dan pemikiran yang bersifat fitrah, menuju manusia yang seutuhnya dan memiliki pola pemikiran yang integralistik, serta berprinsip hanya karena Allah (Agustian, 2011). Beberapa penelitian yang menghubungkan antara kecerdasan spiritual dengan prestasi belajar mahasiswa adalah salah satunya penelitian dilakukan oleh Basuki (2015) yang menyatakan terdapat pengaruh langsung yang signifikan kecerdasan spiritual terhadap motivasi belajar. Sejalan dengan penelitian yang dilakukan oleh Hapsari (2010) yang menyatakan bahwa terdapat hubungan antara kecerdasan spiritual dengan motivasi belajar pada mahasiswa D IV Kebidanan Fakultas Kedokteran Universitas Sebelas Maret.

Peningkatan motivasi belajar mahasiswa harus terus ditingkatkan agar prestasi yang diperoleh meningkat mengingat persaingan di dunia kerja yang semakin meningkat. Untuk itu persoalan ini segera dipecahkan, salah satunya dengan membangun model peningkatan motivasi mahasiswa PTS yang ada di jawa Timur sebagai upaya untuk meningkatkan prestasi mahasiswa PTS ada di Jawa Timur yang berbasis kompetensi dosen, profesionalisme dosen dan kecerdasan spiritual dosen. Model ini mempunyai keunggulan dalam peningkatan motivasi belajar mahasiswa PTS yang ada di Jawa Timur sehingga dapat bersaing dengan lulusan yang lainnya dalam mendapatkan pekerjaan. Tujuan penelitian untuk mengetahui pengaruh kompetensi dosen, profesionalisme dosen dan kecerdasan spiritual terhadap motivasi belajar mahasiswa pada Universitas Muhammadiyah di Jawa Timur.

\section{METODE PENELITIAN}

\section{Rancangan Penelitian}

Dalam penelitian ini akan dianalisis pengaruh variabel-variabel kompetensi dosen, profesionalisme dosen, kecerdasan spiritual dosen terhadap motivasi belajar 
mahasiswa. Untuk mengetahui pengaruh variabel-variabel kompetensi dosen, profesionalisme dosen, kecerdasan spiritual dosen terhadap motivasi belajar mahasiswa secara individual digunakan uji t, dan untuk mengetahui pengaruh secara serempak digunakan uji F.

\section{Populasi Penelitian, Sample dan Teknik Pengambilan Sampel}

Populasi sebagai wilayah genaralisasi yang terdiri atas obyek/subyek yang mempunyai kuantitas dan karakteristik tertentu ( Ghozali, 2006). Populasi adalah semua obyek atau individu yang memiliki karakteristik tertentu, jelas dan lengkap yang akan diteliti. Populasi penelitian ini adalah seluruh mahasiswa Universitas Muhamamdiyah yang ada di Jawa Timur yang meliputi perguruan tinggi : Universitas Muhammadiyah Sidoarjo, Universitas Muhammadiyah Jember, Universitas Muhammadiyah Gresik, Universitas Muhammadiyah Malang, Universitas Muhammadiyah Ponorogo, Universitas Muhammadiyah Surabaya. Jumlah populasi dalam penelitian ini adalah 56.400 orang (Forlap Dikti, 2018). Metode pengambilan sampel yang digunakan adalah stratified random sampling. Jumlah sampel ditentukan dengan rumus Slovin. Dari hasil rumus Slovin dengan tingkat kesalahan 10\% diperoleh jumlah sampel sebanyak 135 mahasiswa.

\section{Identifikasi Variabel}

Variabel dalam penelitian ini dikelompokkan menjadi 2 yaitu variabel bebas (independen) dan variabel terikat. Variabel bebasnya terdiri dari kompetensi dosen (X1) , profesionalisme dosen(X2), kecerdasan spiritual dosen (X3) dan variabel terikatnya adalah motivasi belajar mahasiswa.

\section{Definisi Operasional Variabel}

\section{Kompetensi Dosen}

Dalam penelitian ini yang menjadi variabel independen adalah kompetensi dosen. Kompetensi dosen merupakan kemampuan dan kewenangan dosen dalam melaksanakan tugasnya. Menurut UU No. 14 Tahun 2005 tentang guru dan dosen dan PP No. 74 Tahun 2008 kompetensi dosen meliputi : kompetensi pedagogik, kompetensi professional, kompetensi kepribadian dan kompetensi social.

\section{Profesionalisme Dosen}

Profesionalisme dosen merupakan kondisi, arah, nilai, tujuan dan kualitas suatu keahlian dan kewenangan dalam bidang pendidikan dan pengajaran yang berkaitan dengan pekerjaan seseorang yang menjadi mata pencaharian. Dosen yang profesional 
merupakan faktor penentu proses pendidikan yang bermutu. Untuk dapat menjadi profesional, mereka harus mampu menemukan jati diri dan mengaktualkan diri. Pemberian prioritas yang sangat rendah pada pembangunan pendidikan selama beberapa puluh tahun terakhir telah berdampak buruk yang sangat luas bagi kehidupan berbangsa dan bernegara. Adapun indikator untuk profesionalisme dosen adalah adalah : Memiliki keahlian khusus, memaksimalkankan kemampuannya, memiliki jati diri.

\section{Kecerdasan Spiritual Dosen}

Kecerdasan spiritual lebih berkaitan dengan pencerahan jiwa. Orang yang memiliki kecerdasan spiritual tinggi mampu memaknai hidup dengan memberi makna positif pada setiap peristiwa, masalah, bahkan penderitaan yang dialaminya (Zonar san Marrshall, 2003). Dengan memberi makna yang positif akan mampu membangkitkan jiwa dan melakukan perbuatan dan tindakan yang positif. Sifat spiritual manusia diketahui dari agama-agama besar di dunia yang mengabarkan bahwa manusia adalah makhluk spiritual yang kini tengah melewati eksistensi fisik sebagai bagian dari perjalanan spiritual kekal manusia. Adapun indikator dari kecerdasan spiritual adalah (Ardana dkk, 2013): 1) Ketrampilan Sosial, 2) Keimanan Pada Tuhan, 3) Kebermaknaan Hidup, 4) Cinta Kasih.

\section{Motivasi Belajar}

Azhad dkk. (2015) menyatakan bahwa motivasi merupakan dorongan yang membuat seseorang untuk melakukan sesuatu pekerjaan yag dapat meningkatkan prestasi diri. Motivasi itu merupakan suatu tenaga (dorongan, alasan kemauan) dari dalam yang menyebabkan kita berbuat/bertindak yang mana tindakan itu diarahkan kepada tujuan tertentu yang hendak dicapai (Afritasari, 2013). Menurut Daud (2012), motivasi berasal dari kata dasar motif, yang diartikan sebagai daya upaya yang mendorong seseorang untuk melakukan sesuatu. Motif dapat dikatakan sebagai daya penggerak dari dalam dan di dalam subjek untuk melakukan akti-vitas-aktivitas tertentu demi mencapai suatu tujuan. Bahkan motif dapat diartikan sebagai suatu kondisi intern (kesiapsiagaan).

\section{Prestasi Mahasiswa}

Prestasi belajar adalah kecakapan yang nyata dan aktual untuk menunjukan kepada aspek kecakapan yang segera dapat didemonstrasikan dan diuji sekarang juga karena merupakan hasil usaha atau proses belajar yang bersangkutan dengan cara atau metode bahan atau materi yang telah dijalankan" (Nenden Sundari, 2008). Dari uraian diatas 
maka dapat diketahui beberapa faktor yang mempengaruhi keberhasilan siswa dalam mencapai hasil belajar yang maksimal. Indikator untuk prestasi mahasiswa adalah Indeks Prestasi Kumulatif (IPK).

\section{Statistik Deskriptif}

Analisis deskriptif digunakan untuk mengetahui nilai rata-rata dari variabel yang digunakan dalam penelitian. Nilai rata-rata dari variabel kompetensi dosen, profesionalisme dosen, kecerdasan spiritual, dan motivasi belajar serta prestasi mahasiswa.

\section{Uji Validitas dan Reliabilitas Instrumen}

Uji validitas ini dilakukan untuk mengetahui sejauh mana suatu alat ukur (kuesioner) dapat mengukur informasi yang diperlukan. Uji validitas data dapat dilakukan dengan menghitung korelasi antara skor masing-masing butir pertanyaan dengan total skor. Untuk menghitung korelasi digunakan rumus korelasi Pearson. Reliabilitas menunjukkan sejauh mana suatu alat ukur yang berupa kuisioner dapat memberikan hasil yang tidak berbeda jika dilakukan pengukuran kembali terhadap subyek yang sama pada waktu yang berlainan. Pengukuran dilakukan dengan cara mengukur korelasi antar hasil jawaban pertanyaan yaitu memakai fasilitas ukur reliabilitas dengan uji statistik Cronbach Alpha $(\alpha)$. Suatu variabel akan dikatakan reliabel jika memberikan nilai Cronbach Alpha > 0,60 ( Ghozali,2006).

\section{Menguji Permodelan dalam SEM}

Permodelan dalam SEM pada dasarnya meliputi : Measurement Model dan Structural Model (Ferdinand, 2004). Measurement Model (model pengukuran) dilakukan untuk mengkonfirmasikan apakah indikator-indikator yang digunakan dapat mengkonfirmasi sebuah faktor atau observed variable mampu mendefinisikan variabel laten. Model pengukuran ini disebut juga dengan Confirmation Factor Analysis (CFA). Sedangkan Structural Model (Model Struktural) menggambarkan hubungan-hubungan diantara variabel laten ( variabel laten eksogen dan variabel laten endogen). Model Struktural disebut juga dengan Structural Equation Model (SEM). 


\section{HASIL DAN PEMBAHASAN}

\section{Diskripsi Variabel}

Analisis deskriptif ditujukan untuk mengamati kecenderungan-kecenderungan dan penyimpangan data setiap variabel penelitian (tendency central) melalui modus indikatorindikatornya masing-masing. Modus merupakan skor yang paling sering muncul dibanding skor-skor lainnya, atau skor yang terbanyak frekuensi pemunculannya dibanding skor lainnya. Dengan kata lain, modus merupakan kecenderungan utama pada setiap indikator, selanjutnya dari modus-modus indikator itu dirangkum menjadi modus variabel penelitian. Hasil analisis statistik deskriptif dapat disarikan dalam tabel berikut.

Berdasarkan hasil perhitungan dapat dinyatakan berkaitan dengan variabel kompetensi dosen $\left(\mathrm{X}_{1}\right)$ Universitas Muhammadiyah di Jawa Timur dipersepsikan "baik" oleh sebagian besar mahasiswa yang dibuktikan dengan diperolehnya nilai modus secara keseluruhan 4. Baiknya persepsi terhadap variabel kompetensi dosen dapat dilihat melalui dosen mengaitkan perkuliahan dengan isu-isu pendidikan yang aktual dan mutakhir, dosen melaksanakan penilaian sesuai dengan tujuan perkuliahan, dosen menguasai materi perkuliahan secara luas dan mendalam, dosen menggunakan hasil penelitian untuk meningkatkan kualitas perkuliahan, dosen berprilaku sesuai dengan ajaran agamanya, dosen menjadi contoh dalam bersikap dan berprilaku, dosen berkomunikasi lisan dalam pembelajaran secara santun dengan mahasiswa, dan dosen menjalin hubungan secara efektif dengan civitas akademika (dosen dan pegawai).

Profesionalisme dosen $\left(\mathrm{X}_{2}\right)$ Universitas Muhammadiyah di Jawa Timur dipersepsikan "cukup baik" oleh sebagian besar mahasiswa yang dibuktikan dengan diperolehnya nilai modus secara keseluruhan 3. Cukup baiknya persepsi terhadap variabel profesionalisme dosen dapat dilihat melalui dosen memiliki suatu keahlian dalam bidang tertentu sesuai dengan bidang profesinya, dosen memiliki ketrampilan yang didasarkan pada konsep dan teori ilmu pengetahuan yang mendalam, dan dosen mampu mengikuti perkembangan melalui aktualisasi diri sejalan dengan dinamika kehidupan yang terus berkembang secara cepat. Kecerdasan spiritual dosen $\left(\mathrm{X}_{3}\right)$ Universitas Muhammadiyah di Jawa Timur dipersepsikan "cukup baik" oleh sebagian besar mahasiswa yang dibuktikan dengan diperolehnya nilai modus secara keseluruhan 3 . Cukup baiknya persepsi terhadap variabel kecerdasan spiritual dosen dapat dilihat melalui dosen memiliki keterampilan untuk berinteraksi, berkomunikasi dan 
berpartisipasi dalam kelompok, dosen memiliki sisi religiusitas dan menjadi pedoman dalam setiap perilakunya, dosen mampu memaknai penderitaan hidup dengan memberikan makna yang positif pada setiap peristiwa, masalah, bahkan penderitaan yang dialaminya, dan dosen senantias memiliki rasa cinta kasih terhadap diri sendiri, orang lain maupun pada alam semesta.

Motivasi belajar (Z) mahasiswa Universitas Muhammadiyah di Jawa Timur dipersepsikan "baik" oleh sebagian mahasiswa yang dibuktikan dengan diperolehnya nilai modus secara keseluruhan 4. Baiknya persepsi terhadap variabel motivasi belajar dapat dilihat melalui mahasiswa disiplin dalam mengikuti perkuliahan, mahasiswa tekun dalam mengerjakan tugas kuliah, mahasiswa meluangkan waktu untuk belajar baik di kampus maupun di rumah, mahasiswa bekerja secara mandiri dalam mengerjakan tugas kuliah, dan mahasiswa berusaha bekerja keras untuk mencapai prestasi terbaik.

\section{Uji Validitas dan Realibilitas}

Suatu alat ukur yang valid, tidak sekedar mampu mengungkapkan data dengan tepat dan memberikan gambaran yang cermat mengenai data tersebut. Kesahihan suatu data apabila faktor loading dari indicator variabel memiliki nilai diatas 0,50 , maka dapat dikatakan bahwa item pertanyaan sebagai penyusun unobserved variable dalam path analysis adalah valid (Ghozali, 2005). Berdasarkan hasil perhitungan dapat diketahui bahwa masing-masing indikator yang digunakan dalam variabel penelitian mempunyai nilai loading factor yang lebih besar dari 0,50 . Hal ini berarti indikator-indikator yang digunakan dalam variabel penelitian ini layak atau valid digunakan sebagai pengumpul data.

Uji alat ukur (kuesioner) yang kedua adalah reliabel, yaitu indeks yang menunjukkan sejauh mana alat ukur dapat diandalkan atau dapat dipercaya. Reliabilitas adalah ukuran konsistensi internal dari indikator-indikator sebuah variabel bentukan yang menunjukkan derajat sampai dimana masing-masing indikator itu mengindikasikan sebuah variabel bentukan yang umum. Pada penelitian ini dalam menghitung reliabilitas menggunakan composite (contruct) reliability dengan cut off value adalah minimal 0,70 (Solimun, 2002).

Berdasarkan hasil perhtungan ternyata masing-masing variabel laten yang digunakan dalam penelitian memberikan nilai CR di atas nilai cut-off-nya sebesar 0,7 sehingga dapat dikatakan masing-masing variabel laten reliabel. Setelah dilakukan uji 
validitas dan reliabilitas pada masing-masing variabel laten, maka dilakukan uji asumsi untuk melihat apakah prasyarat yang diperlukan dalam permodelan SEM dapat terpenuhi. Prasyarat yang harus dipenuhi adalah asumsi multivariat normal, tidak adanya multikolinearitas atau singularitas dan outlier.

\section{Analisis Structural Equation Modelling (SEM)}

Pada tahap ini akan dibahas mengenai uji kesesuaian model dan uji signifikansi kausalitas. Hasil pengujian dengan program AMOS versi 16.0 memberikan hasil model SEM seperti terlihat pada gambar berikut yang menunjukkan pengaruh kompetensi dosen, profesionalisme dosen, dan kecerdasan spiritual dosen terhadap motivasi belajar dan prestasi mahasiswa pada Universitas Muhammadiyah di Jawa Timur.

Tabel 1. Indeks Kesesuaian SEM

\begin{tabular}{llll}
\hline Kriteria & Nilai Cut Off & Hasil Pengujian & Keterangan \\
\hline Chi Square & $\begin{array}{l}\text { Diharapkan lebih } \\
\text { kecil dari } X^{2} \text { pada } \\
\end{array}$ & $\begin{array}{l}\text { 188,785 } \\
\text { df }=169, \text { yaitu }\end{array}$ & Baik \\
\hline Sig. Probability & $\geq 0,05$ & 0,142 & \\
\hline RMSEA & $\leq 0,08$ & 0,030 & Baik \\
\hline GFI & $\geq 0,90$ & 0,890 & Baik \\
\hline AGFI & $\geq 0,90$ & 0,850 & Marginal \\
\hline CMIN/DF & $\leq 2$ atau 3 & 1,117 & Marginal \\
\hline TLI & $\geq 0,95$ & 0,978 & Baik \\
\hline CFI & $\geq 0,95$ & 0,982 & Baik \\
\hline
\end{tabular}

Sumber: Data Diolah 2018.

Berdasakan tabel 1 tersebut dapat diketahui bahwa dari delapan kriteria yang digunakan untuk menilai layak/tidaknya suatu model terdapat enam kriteria yang telah terpenuhi. Sehingga dapat dinyatakan bahwa model dapat diterima yang berarti ada kesesuaian model dengan data.

a. Uji Kausalitas

Setelah dilakukan pengujian kesesuian modal penelitian, maka langkah selanjutnya adalah menguji kausalitas yang dikembangkan dalam penelitian tersebut. Dari model yang sesuai, maka dapat diinterpretasikan masing-masing koefisien jalur. Pengujian koefisien jalur secara rinci disajikan dalam tabel berikut. 
Tabel 2. Hasil Uji Kausalitas

\begin{tabular}{|c|c|c|c|c|c|c|}
\hline & & Estimate & S.E. & C.R. & $\mathbf{P}$ & Label \\
\hline $\bar{Z}$ & $<---\quad X 1$ & 0,345 & 0,132 & 2,611 & 0,009 & Signifikan \\
\hline $\mathrm{Z}$ & $<---\quad X 2$ & 0,168 & 0,083 & 2,015 & 0,044 & Signifikan \\
\hline Z & $<---\quad X 3$ & 0,068 & 0,064 & 1,055 & 0,291 & Tidak Signifikan \\
\hline
\end{tabular}

Sumber: Data Diolah 2018.

Berdasarkan Tabel 2 dapat dinyatakan bahwa hasil pengujian koefisien jalur untuk pengaruh kompetensi dosen $\left(\mathrm{X}_{1}\right)$ terhadap motivasi belajar $(\mathrm{Z})$ memiliki jalur positif sebesar 0,345 dengan C.R sebesar 2,611 dan probabilitas (p) sebesar 0,009 yang berarti bahwa kompetensi dosen berpengaruh signifikan terhadap motivasi belajar. Sehingga dapat dinyatakan bahwa kompetensi dosen berpengaruh signifikan terhadap motivasi belajar mahasiswa Universitas Muhammadiyah di Jawa Timur. Hal ini berarti semakin baik kompetensi dosen, maka motivasi belajar mahasiswa juga akan semakin baik.

Hasil pengujian koefisien jalur untuk pengaruh profesionalisme dosen $\left(\mathrm{X}_{2}\right)$ terhadap motivasi belajar (Z) memiliki jalur positif sebesar 0,168 dengan C.R sebesar 2,015 dan probabilitas (p) sebesar 0,044 yang berarti bahwa profesionalisme dosen berpengaruh signifikan terhadap motivasi belajar. Sehingga dapat dinyatakan bahwa profesionalisme dosen berpengaruh signifikan terhadap motivasi belajar mahasiswa Universitas Muhammadiyah di Jawa Timur. Hal ini berarti semakin baik profesionalisme dosen, maka motivasi belajar mahasiswa juga akan semakin baik.

Hasil pengujian koefisien jalur untuk pengaruh kecerdasan spiritual dosen $\left(\mathrm{X}_{3}\right)$ terhadap motivasi belajar (Z) memiliki jalur positif sebesar 0,068 dengan C.R sebesar 1,055 dan probabilitas (p) sebesar 0,291 yang berarti bahwa kecerdasan spiritual dosen tidak berpengaruh signifikan terhadap motivasi belajar. Sehingga dapat dinyatakan bahwa kecerdasan spiritual dosen tidak berpengaruh terhadap motivasi belajar mahasiswa Universitas Muhammadiyah di Jawa Timur. Hal ini berarti kecerdasan spiritual dosen tidak secara langsung meningkatkan motivasi belajar mahasiswa.

\section{Pembahasan}

\section{Pengaruh Kompetensi Terhadap Motivasi Belajar}

Hasil penelitian menunjukkan faktor kompetensi dosen mempunyai pengaruh yang signifikan terhadap motivasi belajar. Sehingga dapat dinyatakan bahwa kompetensi dosen berpengaruh signifikan terhadap prestasi mahasiswa Universitas Muhammadiyah 
di Jawa Timur. Hal ini berarti semakin baik kompetensi dosen, maka prestasi mahasiswa juga akan semakin baik. Dosen yang berkompeten pada umumnya dilihat dari seberapa jauh dosen menguasai materi dan dosen tersebut dapat menerapkan model pembelajaran yang tepat untuk materi yang dipelajari. Pendidik yang berkompeten adalah pendidik yang memiliki keterampilan memberi penguatan, bertanya, mengadakan variasi, menjelaskan, dan membuka dan menutup pelajaran. Kompetensi profesional dosen adalah kemampuan (baik pengetahuan, sikap dan keterampilan) yang harus dimiliki oleh seorang dosen untuk melaksanakan dan mempertanggungjawabkan tugas-tugasnya sesuai dengan petunjuk yang telah ditetapkan. Mengacu pada Undang-Undang RI No. 14 Tahun 2005 tentang guru dan dosen, untuk dapat menjadi dosen yang profesional seseorang harus memiliki empat kompetensi yakni kompetensi pedagogik, kompetensi kepribadian, kompetensi sosial dan kompetensi profesional. Kompetensi dosen dapat terlihat jelas apabila ia memiliki nilai berfikir tinggi serta memiliki komitmen (tanggungjawab) yang besar dalam melaksanakan tugas mengajar. Melihat betapa beratnya tanggungjawab dosen terhadap kesuksesan usaha pendidikan maka konsekuensi dosen dalam tugas mengajar harus benar-benar profesional. Karena dengan profesinya, seorang dosen dapat menekuni dan menghayati pekerjaannya sehingga selalu berusaha untuk meningkatkan kualitas dirinya. Ketika membicarakan kegiatan belajar mengajar dalam dunia kampus, tak pernah terlepas dari sosok dosen, karena profil seorang dosen merupakan cermin yang paling diperhatikan oleh mahasiswa dalam proses belajar mengajar. Bahkan ada anggapan, keberhasilan usaha pendidikan di kampus terletak pada bagaimana sikap, kemampuan dan tanggung jawab seorang dosen dalam menjalankan tugas mengajarnya. Kompetensi yang baik dari dosen akan meningkatkan kualitas atmosfir akademik serta meningkatkan motivasi belajar mahasiswa. Ambarita (2016) menyatakan bahwa kompensi dosen dapat meningkatkan motivasi belajar. Tahrir (2013) menyatakan terdapat hubungan yang positif antara kompetensi dengan motivasi belajar.

\section{Pengaruh Profesionalisme Dosen Terhadap Motivasi Belajar}

Hasil penelitian menunjukkan faktor profesionalisme dosen mempunyai pengaruh yang signifikan terhadap motivasi belajar. Sehingga dapat dinyatakan bahwa profesionalisme dosen berpengaruh signifikan terhadap prestasi mahasiswa Universitas Muhammadiyah di Jawa Timur. Hal ini berarti semakin baik profesionalisme dosen, 
maka prestasi mahasiswa juga akan semakin baik. Profesionalisme dosen merupakan kondisi, arah, nilai, tujuan dan kualitas suatu keahlian dan kewenangan dalam bidang pendidikan dan pengajaran yang berkaitan dengan pekerjaan seseorang yang menjadi mata pencaharian. Dosen yang profesional merupakan faktor penentu proses pendidikan yang bermutu. Untuk dapat menjadi profesional, mereka harus mampu menemukan jati diri dan mengaktualkan diri. Profesionalisme menunjuk kepada komitmen para anggota suatu suatu profesi untuk meningkatkan kemampuan profesionalnya dan terus menerus mengembangkan strategi-strategi yang digunakannya dalam melakukan pekerjaan yang sesuai dengan profesinya. Profesionalisme merupakan sikap yang lahir dari keyakinan terhadap pekerjaan yang dipegang sebagai sesuatu yang bernilai tinggi sehingga dicintai secara sadar, dan hal tersebut nampak dari upaya yang terus-menerus dan berkelanjutan dalam melakukan perbaikan yang tiada henti. Dosen profesional berupaya untuk mewujudkan sikap (aptitude) dan perilaku (behavior) ke arah menghasilkan mahasiswa yang mempunyai keinginan, tekad dan kemampuan memajukan profesi yang berdasarkan ilmu dan teknologi. Dengan sikap dan perilaku, dosen melakukan perbaikan yang berkelanjutan, meningkatkan efisiensi secara kreatif melalui upaya peningkatan produktivitas dan optimalisasi pendayagunaan sumber-sumber yang ada di sekitarnya. Berdasarkan uraian tersebut, dapat dinyatkan bahwa profesioanlisme dosen dapat mendorong peningkatan motivasi belajara mahasiswa. Manahen (2010) menyatakan terdapat pengaruh yang signifikan antara profesionalisme guru terhadap motivasi belajar siswa. Mahfud dkk. (2017) menyatakan bahwa terdapat pengaruh yang positif antara profesionalisme guru terhadap motivasi belajar siswa.

\section{Pengaruh Kecerdasan Spiritual Dosen Terhadap Motivasi Belajar}

Hasil penelitian menunjukkan faktor kecerdasan spiritual dosen tidak mempunyai pengaruh yang signifikan terhadap motivasi belajar. Sehingga dapat dinyatakan bahwa kecerdasan spiritual dosen tidak berpengaruh terhadap motivasi belajar mahasiswa Universitas Muhammadiyah di Jawa Timur. Hal ini berarti kecerdasan spiritual dosen tidak secara langsung meningkatkan motivasi belajar mahasiswa. Pengaruh yang tidak signifikan kecerdasan spiritual dosen terhadap motivasi belajar bisa disebabkan masih kurangnya intensitas komunikasi dua arah antara mahasiswa dan dosen. Seringkali, dosen hanya menjalankan tugas mengajar, tanpa disertai adanya pendekatan komunikatif 
dengan mahasiswa, sehingga mahasiswa kurang mengenal dosennya dan termasuk mengenai aspek spiritualitas dosen. Kondisi ini tentunya menjadi kendala bagi dosen untuk mampu meningkatkan motivasi mahasiswanya.

Kecerdasan spiritual lebih berkaitan dengan pencerahan jiwa. Orang yang memiliki kecerdasan spiritual tinggi mampu memaknai hidup dengan memberi makna positif pada setiap peristiwa, masalah, bahkan penderitaan yang dialaminya. Dengan memberi makna yang positif akan mampu membangkitkan jiwa dan melakukan perbuatan dan tindakan yang positif. Sifat spiritual manusia diketahui dari agama-agama besar di dunia yang mengabarkan bahwa manusia adalah makhluk spiritual yang kini tengah melewati eksistensi fisik sebagai bagian dari perjalanan spiritual kekal manusia. Penelitian ini tidak sejalan dengan penelitian Hapsari (2010) menyatakan bahwa terdapat pengaruh yang positif antara kecerdasan spiritual terhadap motivasi belajar.

\section{KESIMPULAN DAN SARAN}

\section{Kesimpulan}

Berdasarkan analisis yang telah dilakukan pada penelitian ini, maka dapat ditarik kesimpulan sebagai berikut:

1. Kompetensi dosen berpengaruh signifikan terhadap motivasi belajar mahasiswa Universitas Muhammadiyah di Jawa Timur.

2. Profesionalisme dosen berpengaruh signifikan terhadap motivasi belajar mahasiswa Universitas Muhammadiyah di Jawa Timur.

3. Kecerdasan spiritual dosen tidak berpengaruh signifikan terhadap motivasi belajar mahasiswa Universitas Muhammadiyah di Jawa Timur.

\section{Saran}

Mengacu pada kesimpulan di atas, maka dapat dapat diberikan saran sebagai berikut.

1. Hasil penelitian menunjukkan bahwa kompetensi dosen, profesionalisme dosen, dan kecerdasan spiritual dosen berpengaruh terhadap motivasi mahasiswa Universitas Muhammadiyah di Jawa Timur. Oleh karena itu, perlunya upaya peningkatan kompetensi dosen, profesionalisme dosen, dan kecerdasan spiritual dosen yang dapat dilalukan melalui peningkatan atau update bahan ajar, peningkatan fasilitas 
pengajaran, pelaksanaan evaluasi belajar secara objektif dan transparan, serta mendorong dosen untuk mengikuti berbagai seminar dan kegiatan penelitian.

2. Bagi penelitian lanjutan disarankan untuk menambahkan variabel lain seperti lingkungan belajar, fasilitas, dan lain-lain. Selain itu, perlu adanya keterlibatan secara langsung dari peneliti, sehingga objektivitas penelitian bisa tercapai. Sehingga dapat memperoleh hasil temuan yang lebih baik dalam menjelaskan prestasi belajar dan berguna bagi pengembangan ilmu pengetahuan.

\section{DAFTAR PUSTAKA}

Afritasari, Sofia, 2013.” Pengaruh Kompetensi Dosen Dan Motivasi Belajar Terhadap Prestasi Belajar Mahasiswa”. Laporan Peneltian Tidak Dipublikasikan. Program Studi Magister Kedokteran Keluarga. Universitas Sebelas Maret Surakarta.

Afritasari, Sofia, 2013." Pengaruh Kompetensi Dosen Dan Motivasi Belajar Terhadap Prestasi Belajar Mahasiswa". Laporan Peneltian Tidak Dipublikasikan. Program Studi Magister Kedokteran Keluarga. Universitas Sebelas Maret Surakarta.

Agustian, Ary Ginanjar. 2001. Rahasia Sukses Membangun Kecerdasan Emosi dan Spiritual, ESQ:Emotional Spiritual Quotient berdasarkan 6 Rukun Iman dan 5 Rukun Islam. Jakarta: ArgaWijayaPersada.

Agustian, Ary Ginanjar. 2001. Rahasia Sukses Membangun Kecerdasan Emosi dan Spiritual, ESQ:Emotional Spiritual Quotient berdasarkan 6 Rukun Iman dan 5 Rukun Islam. Jakarta: ArgaWijayaPersada.

Alamsyah, Sakti. 2013." Pengaruh Kompetensi Pedagogik Dosen Terhadap Prestasi Belajar Mahasiswa".Jurnal UMMI. Universitas Muhammadiyah Sukabumi.

Ambarita, Indah. 2016. Pengaruh Kompetensi Mengajar Dosen Dan Fasilitas Belajar Terhadap Prestasi Akademik Mahasiswa Melalui Motivasi Belajar Mahasiswa Di Stmik Kaputama Kota Binjai. Tesis. Magister Ilmu Manajemen Fakultas Ekonomi Dan Bisnis Universitas Sumatera Utara Medan.

Andriawati, Eka. 2013."Pengaruh Kompetensi Pedagogik Guru Terhadap Hasil Belajar Siswa Pada Mata Pelajaran Ekonomi Di Sma”. Laporan Peneltian Tidak Dipublikasikan. Fakultas Keguruan Dan Ilmu Pendidikan Universitas Tanjungpura Pontianak.

Ardana,I Cenik, Lerbin R. Aritonang\& Elizabeth Sugiarto Dermawan. 2013.’'Kecerdasan Intelektual, Kecerdasan Emosional, Kecerdasan Spiritual, Dan Kesehatan Fisik Untuk Memprediksi Prestasi Belajar Mahasiswa Akuntansi”.JurnalAkuntansi/Volume XVII, No. 03, September 2013: 444-458. 
Azhad, M Naely. 2015 Manajemen Sumberdaya Manusia. Jember. Cahaya Ilmu.

Basuki, Kasih Haryo. 2015. Pengaruh Kecerdasan Spiritual Dan Motivasi Belajar Terhadap Prestasi Belajar Matematika. Jurnal Formatif 5(2): 120-133, ISSN: 2088-351X.

Daud, Firdaus, 2012." Pengaruh Kecerdasan Emosional (EQ) dan Motivasi Belajar Terhadap Hasil Belajar Biologi Siswa SMA 3 Negeri Kota Palopo".JurnalPendidikan Dan Pembelajaran, Volume 19, Nomor 2, Oktober 2012.

Daud, Firdaus, 2012." Pengaruh Kecerdasan Emosional (EQ) dan Motivasi Belajar Terhadap Hasil Belajar Biologi Siswa SMA 3 Negeri Kota Palopo".JurnalPendidikan Dan Pembelajaran, Volume 19, Nomor 2, Oktober 2012.

Dhermawan, Anak Agung Ngurah Bagus, I Gde Adnyana Sudibya dan I Wayan Mudiartha Utama. 2012."Pengaruh Motivasi, Lingkungan Kerja, Kompetensi, Dan Kompensasi Terhadap Kepuasan Kerja Dan Kinerja Pegawai Di Lingkungan Kantor Dinas Pekerjaan Umum Provinsi Bali”.Jurnal Manajemen, Strategi Bisnis, dan Kewirausahaan Vol. 6, 173 No. 2 Agustus 2012.

Dimyati dan Mudjiono. (2009). Belajar dan Pembelajaran. Jakarta: Rineka Cipta.

Fitri, Yulianti. (2012). Hubungan Kompetensi Pedagogik Guru PAI dengan prestasi Belajar pada PAI.JurnalTarbawi Vol. 1 No. 2 Juni 2012.

Ghozali, Imam. 2006. Aplikasi Analisis Multivariate Dengan Program SPSS. Semarang. Badan Penerbit Universitas Diponegoro.

Ghozali, Imam. 2006. Aplikasi Analisis Multivariate Dengan Program SPSS. Semarang. Badan Penerbit Universitas Diponegoro.

Goleman, Daniel. 2006. Emotional Intelligence, Kecerdasan Emosional Mengapa EI Lebih Penting daripada IQ. Jakarta: PT. GramediaPustakaUtama.

Goleman, Daniel. 2006. Emotional Intelligence, Kecerdasan Emosional Mengapa EI Lebih Penting daripada IQ. Jakarta: PT. GramediaPustaka Utama.

Hapsari, Riska Pramita. 2010. Hubungan Antara Kecerdasan Spiritual Dengan Motivasi Belajar Pada Mahasiswa D IV Kebidanan Fakultas Kedokteran Universitas Sebelas Maret. Laporan Penelitian. Program Studi D IV Kebidanan Fakultas Kedokteran Universitas Sebelas MaretSurakarta

Harmaini. 2012.“Pengaruh Persepsi Siswa Tentang Profesionalitas Guru Mengajar dan Motivasi Belajar Terhadap Hasil Belajar Bahasa Indonesia pada SMK Se-Kota Bangkinang”. Jurnal Bahasa Vol. 2, Nomor 2 Oktober 2012. 
Jamaluddin, Tadjuddin Maknun, dan Mustafa Makka, 2012. ” Pengaruh Kompetensi Guru Bahasa Indonesia Terhadap Hasil Belajar Bahasa Indonesia Siswa Sma Negeri 1 Tamalatea Kabupaten Jeneponto. Laporan Penelitian Tidak Dipublikasikan. Program Pascasarjana Fakultas Ilmu Budaya Universitas Hasanuddin Makassar.

Mahmud, Fahd. Rosman Ilato, dan Roy Hasiru 2017. Pengaruh Profesionalisme Guru Terhadap Motivasi Belajar Siswa Pada Mata Pelajaran Akuntansi Di Kelas XI IPS 2 SMA Negeri 4 Gorontalo. Laporan Penelitian Jurusan Pendidikan Ekonomi Fakultas Ekonomi dan Bisnis Universitas Negeri Gorontalo

Manahen, Hania. 2010. Pengaruh Profesionalisme Guru Terhadap Motivasi Belajar Para Siswa SMP Tarakanita Solo Baru Grogol Sukoharjo. Laporan Penelitian Tidak Dipublikasikan Program Studi Ilmu Kependidikan Kekhususan Pendidikan agama Katholik Universitas Sanatha Dharma Yoyakarta.

Mappeasse, Muh Yusuf. 2009. "Pengaruh Cara Dan Motivasi Belajar Terhadap Hasil Belajar Programmable Logic Controller (Plc) Siswa Kelas III Jurusan Listrik Smk Negeri 5 Makassar". Jurnal MEDTEK, Volume 1, Nomor 2, Oktober 2009.

Martini dan Welas. 2013. "Analisis Kompetensi Dosen Dan Kondisi Lingkungan Dalam Upaya Meningkatkan Motivasi Belajar Mahasiswa”. Laporan Penelitian Tidak Dipublikasikan. Fakultas Ekonomi Universitas Budi Luhur.

Martini dan Welas. 2013. “Analisis Kompetensi Dosen Dan Kondisi Lingkungan Dalam Upaya Meningkatkan Motivasi Belajar Mahasiswa”. Laporan Penelitian Tidak Dipublikasikan. Fakultas Ekonomi Universitas Budi Luhur.

Nenden, Sundari. 2008. "Perbandingan Prestasi Belajar Antara Siswa Sekolah Dasar Unggulan dan Siswa Sekolah Dasar Non-Unggulan di Kabupaten Serang”. Jurnal Pendidikan Dasar. Hlm. 23 - 30.

Nurjanah, 2011.“ Pengaruh Profesionalisme Guru Terhadap Prestasi Siswa Pada Mata Pelajaran Al Qur'an Hadits Di Madrasah Ibtidaiyah Se Kecamatan Gemuh Kabupaten Kendal Tahun 2010". Laporan Penelitian Tidak Dipublikasikan. Fakultas Tarbiyah Institut Agama Islam Negeri Walisongo Semarang.

Oktarina, Ivana Kun, 2011. “ Pengaruh Profesionalisme Guru Mata Pelajaran Ilmu Pengetahuan Sosial Terhadap Prestasi Belajar Siswa Kelas VII Rintisan Madrasah Bertaraf Internasional Dan Akselerasi Di Madrasah Tsanawiyah Negeri Malang III". Laporan Penelitian Tidak dipublikasikan. Program Studi Pendidikan Ekonomi Jurusan Pendidikan Ilmu Pengetahuan Sosial Fakultas Tarbiyah Universitas Islam Negeri Maulana Malik Ibrahim Malang.

Parauba, Inriawati. 2013." Pengaruh Kecerdasan Intelektual, Kecerdasan Emosional, Cerdasan Spiritual, Dan Perilaku Belajar Terhadap Pemahaman akuntansi Mahasiswa". Laporan Penelitian Tidak Dipublikasikan. Fakultas Ekonomi Dan Bisnis Universitas Sam Ratulangi Manado. 
Rachmi, Filia. 2012. "Pengaruh Kecerdasan Emosional, Kecerdasan Spiritual, Dan Perilaku Belajar Terhadap Tingkat Pemahaman Akuntansi". Laporan Penelitian Tidak Dipublikasikan, Universitas Diponegoro Semarang.

Rachmi, Filia. 2012. "Pengaruh Kecerdasan Emosional, Kecerdasan Spiritual, Dan Perilaku Belajar Terhadap Tingkat Pemahaman Akuntansi”. Laporan Penelitian Tidak Dipublikasikan, Universitas Diponegoro Semarang.

Rapareni, Yussi. 2013. "Analisis Pengaruh Kompetensi Komunikasi, Kecerdasan Emosional, Dan Budaya Organisasi Terhadap Kinerja Karyawan Radio Republik Indonesia Palembang”. JurnalEkonomi Dan InformasiAkuntansi (Jenius).Vol. 3 No. 1Januari 2013.

Ruky, A. 2006. Sumber Daya Manusia Berkualitas MengubahVisiMenjadiRealitas. CetakanKedua.Jakarta: PT. GramediaPustakaUtama.

Sofyana, Dian Maya, 2008. “ Profesionalisme Guru Dan Hubungannya Dengan PrestasiBelajarSiswa Di MtsAl-Jamii'AhTegallegaCidologSukabumi”. LaporanPenelitianTidakDipublikasikan.JurusanPendidikan Agama IslamFakultasIlmuTarbiyah Dan KeguruanUinSyarifHidayatullahJakarta.

Tahrir. 2013. Pengaruh Kompetensi Dosen Terhadap Motivasi Belajar Pada Mahasiswa Fakultas Psikologi UIN "SGD” Bandung. Psympathic, Jurnal Ilmiah Psikologi 2013, Vol. VI, No.1: 756 - 765.

Zohar, Danah dan Ian, Marshall. 2003. SQ Kecerdasan Spiritual. Bandung: MIZAN. 